\title{
腹診教育用シミュレータの開発
}

\author{
矢久保修嗣 $\mathrm{a}$ 優子 $\mathrm{a}$ 安藝 竜彦 ${ }^{\mathrm{a}}$ \\ 太田浩b
}

a 日本大学医学部内科学系統合和漢医薬学分野, 東京, $\overline{7}$ 173-8610 板橋区大谷口上町 30-1

b 日本大学産官学知財センター, 東京, $=102-8275$ 千代田区九段南4-8-24

\section{Improvement of A Simulator Production Project for Abdominal Palpation in Kampo Medical Training}

\author{
Shuji YAKUBO ${ }^{\mathrm{a}}$ \\ Yuko KINOSHITA ${ }^{\mathrm{a}}$ \\ Tatsuhiko $\mathrm{AKI}^{\mathrm{a}}$ \\ Hiroshi OTA ${ }^{\mathrm{b}}$ \\ a Nihon University School of Medicine, Department of Medicine, Division of Integrated Herbal Medicine, 30-1 Ohyaguchi- \\ Kamicho, Itabashi-ku, Tokyo 173-8610, Japan \\ b Nihon University Business, Research and Intellectual Property Center, 4-8-24 Kudan-minami, Chiyoda-ku, Tokyo 102-8275, \\ Japan
}

\begin{abstract}
In Kampo medicine, sickness is regarded as affecting the whole body even though the symptoms may appear obvious only in the abdomen. This makes abdominal palpation an important means of physical examination, and diagnosis. Because learning abdominal palpation in the Kampo style is very difficult, we attempted to simplify learning by building typical anatomical abdomen models for training. To create six abdominal models : Shinka-hiko, Kyokyo-kuman, Fukuchokukin-renkyu, Shofuku-fujin, Shofuku-koman, and Shinkabusinsuion, we employed several materials, including artificial leather for epidermal tissue, pile fabric for subcutaneous tissue, cotton cloth or jersey cloth for membrane tissue, polyurethane or natural rubber for muscle tissue, specialized polyester resin for costae, and cotton for internal organs. We employed a harder polyurethane, for example, in Shinka-hiko to simulate resistance in the region beneath the heart, in Kyokyo-kuman to simulate resistance in the subcostal region, and in Shofuku-koman to simulate horseshoe-shaped resistance in the lower abdominal region. Otherwise, in Shofuku-fujin, a lack of resistance was simulated by a defect in the polyurethane at the center of the lower abdominal region. Shinkabu-sinsuion was modeled using a water dabbling sound via a water-filled balloon that could be gently shaken with the fist in the region above the navel. Fukuchokukin-renkyu was modeled as excessive strain of the rectus abdominis muscles via the use of natural rubber. We tried to represent the tenderness on pressure at the para-umbilical region, cecal region, and sigmoid region in the Shofuku-koman model by making a specialized switch with conducting rubber, and using electric device and battery. We believe these models are useful teaching devices, in that they simplify Kampo abdominal palpitation training.
\end{abstract}

Key words : Kampo medicine, abdominal diagnosis, abdominal palpation, simulator, medical education, conducting rubber

\section{要旨}

患者から身体所見を得ることは臨床では極めて重要である．漢方医学でも日本で発達してきた腹部の独特な触診 を行う腹診が伝えられてきている，腹診は患者の腹部を医師が触診し，腹証という腹部にみられる所見を得る方法 である.しかし，この腹診の教育では, 学生に手から得られる感覚を教育することや, 典型的な腹証を用意するこ となど困難がある.このため, 典型的な腹証の教育ができるようなシミュレータの作成を行った. これは心下㾂鞕， 胸脇苦満, 小腹硬満, 腹直筋攣急など, 患者の腹部にみられる特定部位における医師が触知する抵抗感や, 小腹不 仁では抵抗減弱感を再現した，また，心下部振水音は，適切な手技により心窝部における拍水音が聴かれるように 工夫した。下腹部にみられる疙血の圧痛に関して，導電性ゴムを用いて特殊なスイッチを作成し，電子音発生装置 を組み込むことにより, 小腹硬満モデルに臍傍, 回盲部、 S 状結腸部の圧痛所見を加えた. この腹診教育用シミュ レータにより．患者の腹部から得られる所見を学生は体験として学ぶことが可能となり, 漢方医学における腹診の 教育に効果を発揮することが期待される. 


\section{はじめに}

患者から診断学上の重要な身体所見を得ることは, 臨床では極めて有用である。漢方医学においても, 日本で発達してきた腹部の触診を行う腹診がある。 この腹診の際には, 患者は仰臥位で下肢は伸展させ る。このことで患者の腹部には適度の緊張が生じて おり，この腹部を医師の手指により触診し，このと き捉えられる医師に伝わる手の感覚や，圧迫に対す る患者の反応などにより，腹証という独特の腹部所

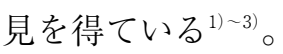

腹証の所見から漢方医学的病態解析が行われ治療 すべき漢方方剤が決定されたり，腹証だけからも治 療に用いられるべき漢方方剂が決定されるなど, 漢 方医学では重要なものである ${ }^{1) 6) 。 ~}$

我々は，この腹診を学生などに教育する際には， 腹部の図を示し，それぞれの所見の出現部位を示し， その所見やそのときの医師の手の使い方やその圧迫 する力などを口述して, その後, 患者にみたてた学 生の腹部を診察するなどして教育を行ってきた。

しかし，腹診時の医師の手指の動きや，圧迫する 圧力やそのとき手に得られる抵抗感などを教育する ことは, 感覚的な問題も存在するためかなり困難で ある。また，実際の患者においても典型的な腹証所 見を全て用意することは不可能であり，かつ圧痛の ある所見では患者の負担も大きいなど, 腹診教育に は困難がみられる。

このため，典型的な腹証の教育が可能となるよう な腹診教育用シミュレータの作成を行った。

\section{材料および方法}

腹診教育用シミュレータは腹証を再現することを 目的としているために, 剣状突起部付近から臍下約 $30 \mathrm{~cm}$ までの腹部のみで構成される腹部模型として 作成した。この腹部模型の素材には，可塑性のある 特殊ポリエステル系樹脂, 人工皮革, パイル生地, 綿, 木綿生地, ジャージ, ポリウレタン, 天然ゴム で，特殊ポリエステル系樹脂などを使用した（表 1 )。人体が様々な組織の層構造でできていること を考慮し前記の素材を重ねて用いて, 実際の腹証に 近い感触を得られるように作成した。これに加えて， 领血の圧痛に対する生体の反応を示すようなシステ ムを作成した。
以下の 6 種類の典型的な腹証を表現する 6 個の腹 部モデルの作成を行った（図 1 )。これには，(a)胸 脇苦満モデル, (b)心下痞鞕モデル, (c) 腹直筋攣急 モデル，(d)小腹不仁モデル，(e)心下部振水音モデ ル，(f) 小腹硬満・疼血の圧痛モデルを作成した。

胸脇苦満モデルでは左右の季肋部を圧迫したとき の抵抗感を, 楕円形 $(100 \times 200 \times 20 \mathrm{~mm})$ のやや硬 めのウレタンを使用して表現した。これを樹脂で作 成した胁骨に，胁骨下に術者の指が入りにくいよう にしっかりと固定した（図１ａ）。

心下㾂鞭モデルでも，樹脂で作成した肋骨によっ て囲まれた心窩部に楕円形 $(15 \times 25 \times 25 \mathrm{~mm})$ のや や硬めのウレタンを置き，触診したときの抵抗とし て表現した（図 1 b)。

腹直筋攣急モデルでは腹直筋の緊張光進を再現す るように，天然ゴムで被覆したもの $(500 \times 100 \times 50$ $\mathrm{mm})$ を 2 本使用して, 触診した際の抵抗感を表現し

\section{た（図 $1 \mathbf{c} ）$}

小腹不仁のモデルでは下腹部正中部のスポンジに 楕円形 $(20 \times 150 \mathrm{~mm})$ の切り欠きを作成し, 触診 した際に同部位の抵抗感が減弱しているようにした

(图 1 d)。

心下部振水音モデルは, 内部に水 $(50 \mathrm{ml})$ と空 気（150ml）を入れたゴム風船を, 柔らかい腹部モ デルの心窩部に置いて作成した（図 1 e)。

小腹硬満モデルでは，楕円形状 $(140 \times 105 \mathrm{~mm})$ のやや硬めのスポンジに, 短径側について $20 \mathrm{~mm} の$ 切り欠きを加え, 形をなめらかに整形し馬蹄形の馬 蹄形の膨隆と抵抗感を表現した（図 $1 \mathbf{f}$ )。

これに加えて小腹硬満モデルに痁血の所見である 下腹部にみられる圧痛を表現するシステムを追加す ることを行った。この圧痛は臍傍, 回盲部, $\mathrm{S}$ 状結 腸部を術者の指頭により, 脊柱の方向に向かって圧 迫すると患者が鋭い圧痛を訴える所見である。小腹 硬満にみられる下腹部の抵抗感と弾力, 柔軟性など を考慮し，かつ圧迫で通電するスイッチを作成し， 痛みを表現する電子音発生装置を組み込んだ。

スイッチは鬼怒川ゴム社製導電性ゴム $\mathrm{S} 60$ を用い て作成した。この導電性ゴムの素材はシリコーンで,

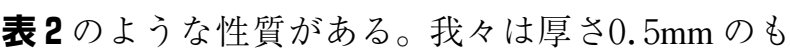
のを使用し，導電性ゴム板を馬蹄形に形成した。こ 
表 1 腹診教育用シミュレータの材料

·表皮 $\rightarrow$ 人工皮革

・皮下組織 $\rightarrow$ パイル生地, スポンジ

・膜 一木綿生地, ジャージ

・筋 $\rightarrow$ ・リ゚リウレタン, 天然ゴム

・胁骨 $\rightarrow$ 特殊ポリエステル系樹脂

·腹腔内臓器 $\rightarrow$ 綿
表 2 導電性ゴム $\mathrm{S} 60$ の規格

\begin{tabular}{|lrl}
\hline 体積固有抵抗值 & $1.0 \sim 9.9$ & $\Omega \cdot \mathrm{cm}$ \\
硬度 & 60 & $\mathrm{JIS} \cdot \mathrm{A}$ \\
引っ張り強度 & 7.1 & $\mathrm{Mpa}$ \\
伸び率 & 280 & $\%$
\end{tabular}

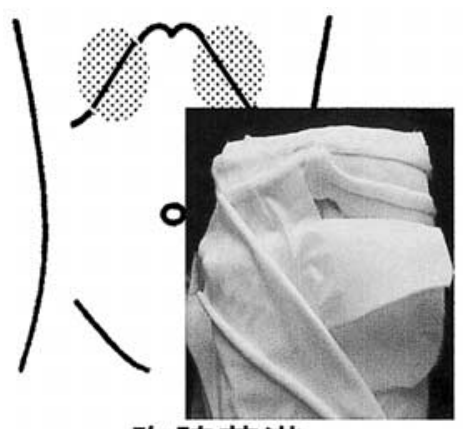

a 胸脇苦満

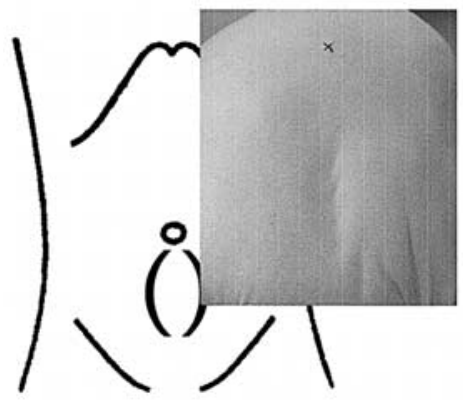

d 小腹不仁

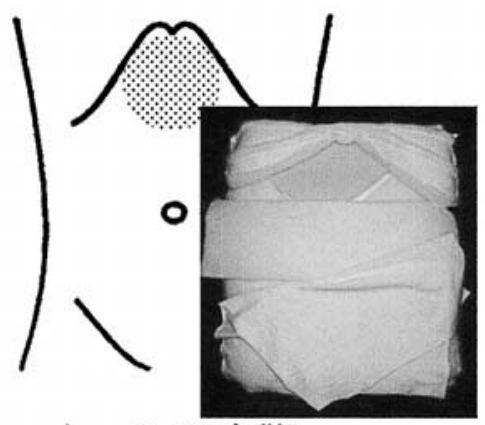

b 心下㾂鞭

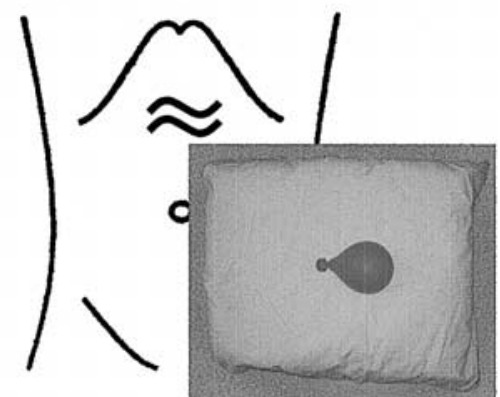

$e$ 心下部振水音 $f$ 小腹硬満・疠血の圧痛

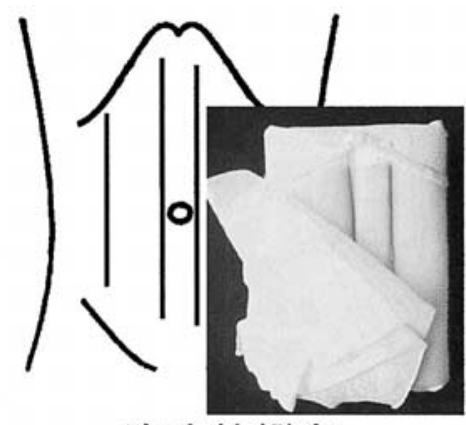

C 腹直筋攣急

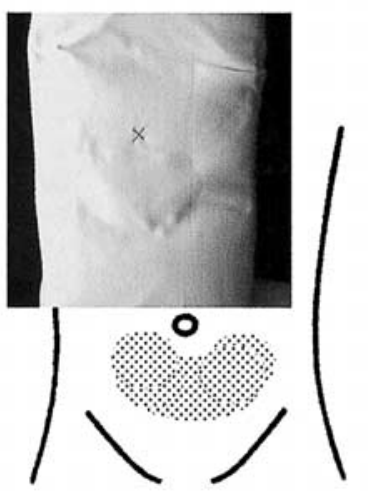

図 16 種類の腹診教育モデル

れと同じ形で厚さ $10 \mathrm{~mm}$ の導電性のないスポンジを 用いて, 臍傍, 回盲部, $\mathrm{S}$ 状結腸部の圧痛点に相当 する部位に直径 $8 \mathrm{~mm}$ の穴を作成した。このスポン ジの角をなめらかに削り, 先ほど作成した 2 枚の導 電性ゴム板で挟み込んた（図２）。

スポンジに作成した穴の直上にある導電性ゴムの 部分を正確に圧迫すると，導電性ゴムが接してこの 部分で電流が流れるようになっている。不適切な圧 迫では導電性ゴムの接触が不十分となり, 電流抵抗 が増加し流れる電流が減少し, 電子音が小さく発生 されるようにした（図３）。このゴム，スポンジを 合わせた構造物をスイッチとしゴム板に 2 本導線を 取り付け，このうち一本の導線には $9 \mathrm{~V}$ 乾電池を取 り付けた（図４）。電子音発生装置と電池を導線で 接続し，スイッチのもう一方の導線を電子音発生装 置に接続した。電子音発生装置は市販のもので, 電 


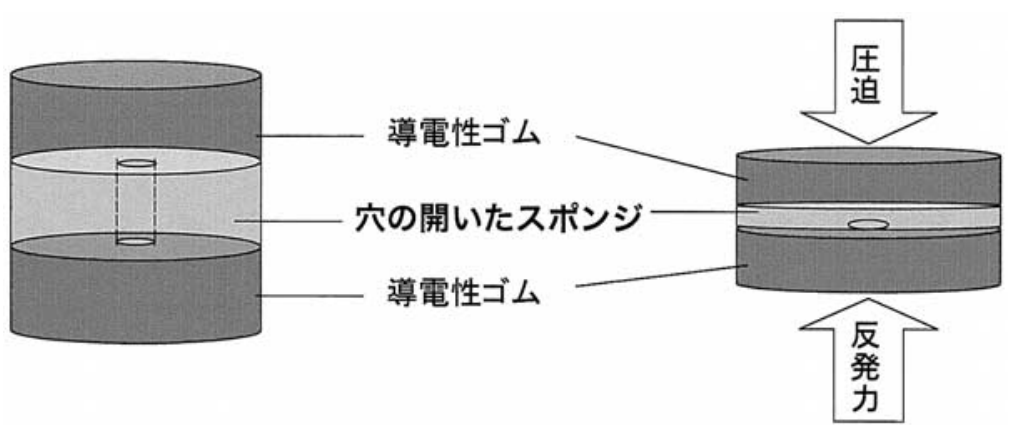

図 2 導電性ゴムとスポンジを用いたスイッチの構造

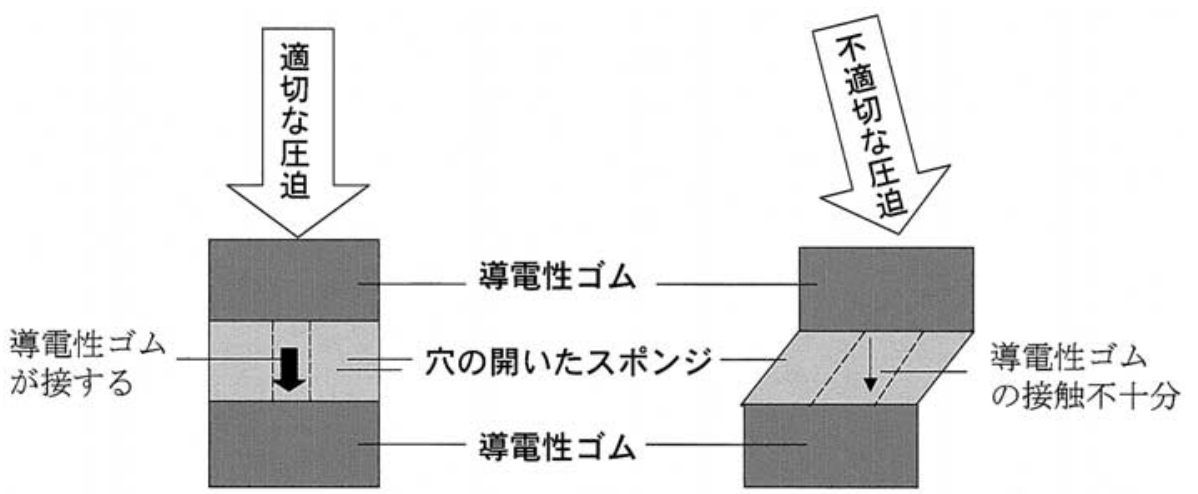

(a) 通電する

(b) 通電不十分

図 3 導電性ゴムとスポンジを用いたスイッチの特徵

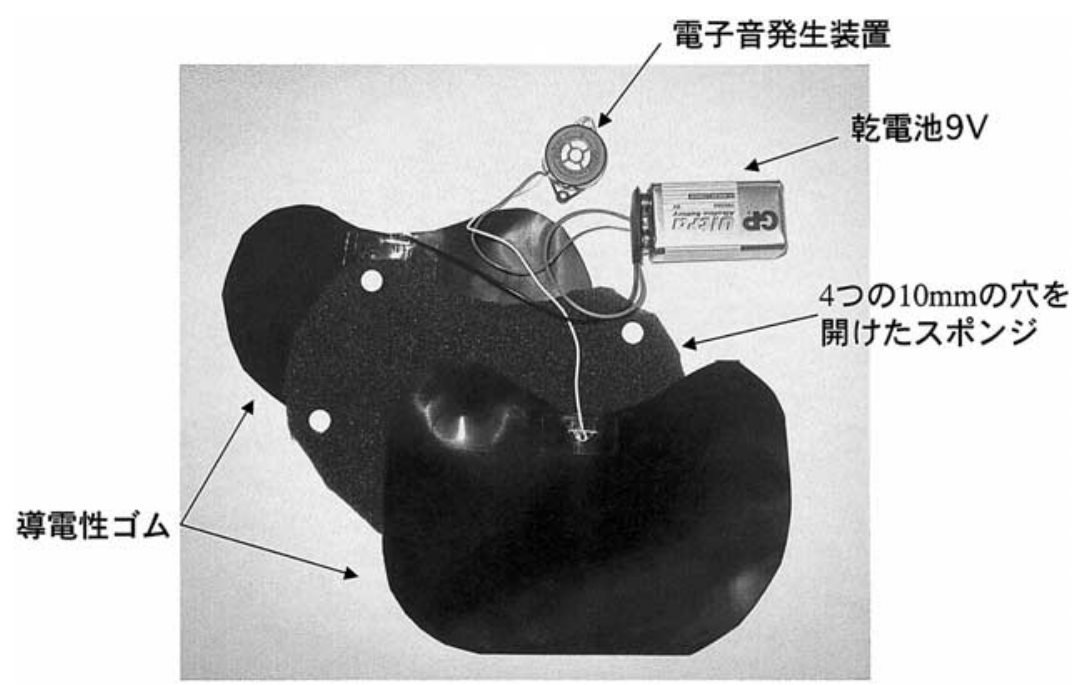

図 4 小腹硬満に瘀血の圧痛を再現するシステムの概要

の膨隆がみられ, 術者が触診した際には抵抗を感じ た。そして, 臍傍部, 回盲部, $\mathrm{S}$ 状結腸部を医師の 指頭により圧迫すると，適切な部位かつ適切な圧迫 方向の圧迫によりスイッチが作動し，通電が行われ 電子音が発生した。不適切な部位の圧迫や，圧迫す る力の方向が斜めとなったりすると, 導電性ゴム同 士の接触できなかったり不充分な接触となり，電子 音の発生が聞かれなかったり，あるいは小さな電子
音であった。

\section{考案}

腹診は古代中国では行われていたと推定されるが, 中国では古い時代に廃絶し我が国で近世以後に復元 した手法である。古代中国医学に由来する医学は東 アジアの諸国，諸地域に継承されているが，腹診を 行う国は認められず，現在では日本独自の手法とい えると, 山田は報告している7 。漢方医学の腹診は 
患者の病態を把握する事を目的とし, 漢方医学独自 の診断基準で治療方針を決定し，処方を決め予後を 判断するものであると，大塚は述べている8 。日本 漢方では処方の鑑別にしばしば腹診が有用であり， 古来，急性疾患は脈診で，慢性疾患は腹診で決めよ と言われており, 腹診は生来の素因・体質, 過去の 病気や生活歴を経て診察時点の腹証を呈するに至っ ていると考えることができると，花輪は記載してお $り^{4)}$, 漢方医学では腹診は重要な診察法である。

腹証について，現代医学的立場からその所見に関 する検討も行われており, 新しい臨床検查機器を用 いることによる腹証の機序や客観的評価を行うため の研究も紹介されている ${ }^{9}$ 。最近では, 小腹不仁の ときにみられる下腹部正中の抵抗減弱を計測するデ ジタル腹診計の開発を宮本らが行っておりり 。我々 は接触型サーモグラフによって腹部の体表温を計測 して腹証の検討 ${ }^{11}$ を行っている。

このように腹診は日本漢方では診断に重要な診断 法であるから, 現在でも, 漢方医学の講演会でもこ れらの手技の講演がなされている ${ }^{6)}$ 。腹証について は, 日本東洋医学会の編集した漢方医学の教科書と 言われている “入門漢方医学”では，腹部の漢方的 な名称を理解することと, 臨床的意義を持つ代表的 腹証を理解することが必要であることが記載されて いる1)。

文部科学省平成13年 3 月 27 日公表の “医学・歯学 教育の在り方に関する調查研究協力者会議” 報告書 に，医学部卒業までの到達目標として“和漢薬を概 説できる”という項目が加わり，平成16年現在，日 本全国80医科大学・医学部の全校において, 学生に 対する漢方医学教育が開始された。

医科大学・大学医学部においては限られた時間の なかで，多くの学生に対して腹診を教育するために， 罒やビデオなどで手技を示したり，パソコンを導入 して効率よく腹証を学習する試み ${ }^{12)}$ な゙も行われて いるが，患者に触れた時の手の感覚を学生に教育す ることはかなり困難である。

医学教育の分野では, 呼吸音や心雑音などの聴覚 で捉えられる生体情報に関するシミュレータや，静 脈注射などの処置を練習するシミュレータなどは開 発されてきている。しかし，日本独自に発展してき た腹診に関するものは作成されたこともなく，我々 のモデルは唯一のものである。
胸脇苦満モデルや, 心下㾂鞕モデル, 腹直筋攣急 モデルでは腹部の相当部位に抵抗感を再現し, 小腹 不仁モデルでは下腹部正中部における抵抗減弱を示 すようにした。心下部振水音モデルでは適切な吒打 により，液体の摇れる音を聴くことができた。

小腹硬満・瘀血の圧痛モデルでは下腹部に馬蹄形 の膨隆と抵抗感を示し, 臍傍部, 回盲部, $\mathrm{S}$ 状結腸 部を圧迫すると電子音が発生するようになった。

このスイッチは接触面積に応じて電気抵抗に変化 が生じ，適切な圧迫では充分な音量の電子音を発生 したが，不適切あるいは不充分な圧迫では電子音は 小さくなった。これは腹診の圧迫手技を学習する上 で優れた装置と考えられた。

今後，このシミュレータを使用した教育効果など にも検討を行う計画である。また，心下㾂鞕モデル や胸脇苦満モデルでも圧痛の表現を再現することや， これに加えて医師により適切な部位が圧迫されたと きの患者の「重苦しい」，「気分が悪い」，「不快」な どの症状を表現するための方法を考えている。さら に腹部および腹部のいろいろな所見部位にあわせて 硬度を変化することが可能な材料を設置し, 遠隔操 作によりその硬度を変化させるような一体化可変型 腹部シミュレータの作成や, 腹部動悸のような動き のあるものを表現できるような装置の組み込みに関 して検討を行っていきたい。

西洋医学に対する限界が知られてきた現在では, 代替医療のひとつとして漢方医学が全世界的にも注 目されている。漢方医学ではその診療に腹診は不可 欠であり,このシミュレータは漢方医学の普及にも 役立つことが期待される。

なお，このシミュレータに関して日本大学産官学 連携知財センター（Nubic）を通して, 特許出願（特 願2006-114556）を行っている。

\section{結語}

漢方医学で重要な腹証について，その典型的な所 見を再現する 6 種類の教育用腹診モデルの作成を 行った。このシミュレータでは, 心下㾂鞕, 胸脇苦 満, 小腹硬満, 小腹不仁, 腹直筋攣急など, 患者の 腹部における特定部位で医師が触知する感覚や，心 下部振水音では適切な手技により心窩部における拍 水音が聴かれるように作成した。

これに加えて, 小腹硬満モデルに導電性ゴムを利 用して特殊なスイッチを作成し，電子部品を用いて 
瘀血の圧痛の再現を行った。

今後, 腹診において心下痞鞕モデルや胸脇苦満モ デルでも圧痛所見の表現を再現することを計画して いる。

この腹診教育モデルにより，患者の腹部から得ら れる有用な所見を体験として学ぶことが可能となり， 漢方医学における腹診の教育に効果を発揮すること が期待される。

\section{文献}

1) 日本東洋医学会学術教育委員会編集 : 入門漢方医 学, 68-81, 南江堂, 東京 (2002)

2 ) 寺澤捷年：症例から学ぶ和漢診療学，188-198, 医学書院，東京（1998）

3 ）大塚敬節 : 漢方医学, 101-107, 創元社, 大阪 (1956)

4 ）花輪壽彦：漢方診療のレッスン, 33-43, 金原出 版，東京 (1995)

5 ）長濱善夫：東洋医学概説，128-138, 創元社, 大 阪 (1961)
6 ）藤平健：第 3 回漢方湯液治療研究会特別公演原稿 腹診と実技，漢方の臨床，41，229-236（1994）

7 ）山田光扸：日本漢方の腹診一大塚敬節先生からの 継承一，漢方の臨床，48，1194-1204（2001）

8 ) 大塚恭男：臨床における四診のこつ 4 切診, 特 に腹診を中心に, 日本東洋医学雑誌，47，376-383 (1996)

9 ) 徳留一博：腹診への現代医学的アプローチーこの 10年の動き一，福岡医師漢方研究会会報， 14，15 (1993)

10）宮本康嗣，沖田極：デジタル漢方腹診計による臍 下不仁測定における再現性と経時変化，漢方と最 新治療，13，185-191（2004）

11）矢久保修嗣，木下優子，荒川泰行：腹診所見に対 する接触型サーモグラフィーの使用経験。和漢医 薬学 (abst.), 19 (supp.), 83 (2002)

12）神正照, 小川陽清：東洋医学における腹診・漢方 学習システム, 東北工業大学情報処理技術研究所 紀要，9，57-67（1996） 